\title{
Identification and characterization of a novel cassava (Manihot esculenta Crantz) clone with high free sugar content and novel starch
}

\author{
Luiz Joaquim Castelo Branco Carvalho, ${ }^{1, *}$, Claudia Regina Batista de Souza ${ }^{1,3}$, Julio \\ César de Mattos Cascardo ${ }^{2}$, Carlos Bloch Junior ${ }^{1}$ and Laura Campos ${ }^{1,4}$ \\ ${ }^{1}$ EMBRAPA Genetic Resources and Biotechnology, Brasilia-DF, Brazil (*author for correspondence; e-mail \\ carvalho@cenargen.embrapa.br); ${ }^{2}$ Departamento de Biologia Celular, Universidade Estadual de Santa Cruz, \\ Ilhéus-BA, Brazil; Current addresses: ${ }^{3}$ Departamento de Genética, Universidade Federal do Para, Belém-PA, \\ Brazil; ${ }^{4}$ Conselho Nacional, Desenvolvimento Cientifico \& Tecnologico (CNPq), Brazil
}

Received 27 June 2003; accepted in revised form 23 February 2004

Key words: cassava, free sugar, novel starch, branching enzyme

\begin{abstract}
This study reports the identification of a new class of cassava (Manihot esculenta Crantz) with a storage root showing unusual free sugar accumulation and novel starch. Twenty-seven clones high in free sugar were identified under cultivation in primitive rural community areas in the Amazon. Iodine test and glucose oxidase-peroxidase reagent strips were used, in the field, for identification of starch and glucose, respectively. Five out of these 27 clones of cassava were cultivated at EMBRAPA Genetic Resources and Biotechnology and used for biochemical characterization, starch synthesis enzyme activities and gene expression analysis. Carbohydrates were fractioned into free sugar, polymerized water-soluble and insoluble $\alpha$-polyglucan. Clones of series CAS36 accumulate over 100 times more free sugar (mainly glucose) than commercial varieties. Monosaccharide composition analysis revealed one clone with distinct watersoluble sugars not present in the commercial cultivar. Structure analysis of the water-soluble and -insoluble $\alpha$-polyglucan revealed the presence of a glycogen-like starch in clone CAS36.1. This clone indicated disruption in the starch synthesis pathway for enzyme activities and protein blot analyses in ADPG-pyrophosphorylase and branching enzyme, and their corresponding protein. Gene expression analysis indicated the lack of transcript for the gene coding for branching enzyme, but not for the gene coding for the ADPGpyrophosphorylase small subunit. In addition, the pattern of distribution of sugar and starch content showed to be related to tissue age in the storage root.
\end{abstract}

\section{Introduction}

A distinct type of cassava (Manihot esculenta Crantz) storage root with a high water content has been known and used since pre-Columbian times among Brazilian Aborigines in the Amazon, under the name of manipueira (Travaço, 1596; Lisboa, 1631; da Cunha, 1978). This type of cassava plant was named mandiocaba by early researchers in the Amazon and its cultivation was abandoned because of its low dry matter content, extremely low starch content $(2 \%)$ and high water content (de
Albuquerque, 1969) relative to cultivars used to produce farina (cassava flour). However, single accessions are still alive and are maintained in germplasm collections organized in Belém (EMBRAPA Amazonia Oriental) and Cruz das Almas (EMBRAPA Cassava and Fruit Crops) as reported in the germplasm catalogue (de Albuquerque, 1969; Fukuda et al., 1996). In spite of this lengthy association with man, no specific biochemical characterization of this type of cassava has been undertaken for centuries. Recently, Carvalho et al. (2000) announced several visits to 
the proposed center of origin and domestication of cassava in Brazil (Allem, 1994; Olsen and Schaal, 1999) in the search for additional diversity on this trait. They have reported the organization of a gene bank with a large number of rare clones, with a storage root showing novel features previously unknown to conventional cassava cultivars, including a high free sugar content (Carvalho et al., 2000). The sugars and starch diversity of these clones are subjected to intensive research in the Laboratory of Biochemistry and Biophysics of EMBRAPA Genetic Resources and Biotechnology, focusing on understanding of the molecular genetics of the sucrose-starch biosynthetic pathway of this type of cassava clone. The combination of classical breeding, involving the search for a null allele germplasm donor, with molecular breeding to identify the functional gene of this null allele is proposed as a strategy to modify the starch properties in cassava.

The possibility of designing starches for industrial use by genetic manipulation, including in cassava (Munyikwa, 1997; Sivad and Preiss 1998), implies the need to understand the biochemical mechanism of starch granule formation. Several mechanisms have already been proposed (Ball et al., 1996; Bogracheva et al., 1998; Waigh et al., 1998; Zeeman et al., 1998; Edwards et al., 1999). None of the proposed mechanisms have yet been shown to operate in vivo. Spontaneous mutations responsible for diversity in the starch structure present in a species' particular genetic background have been used with great success in Arabidopsis (Zeeman et al., 1998), pea (Craig et al., 1998), maize (Singletary et al., 1997), and rice (Nakamura et al., 1996) in order to understand such mechanisms. In the case of the storage root of cassava no mutation of any kind has been reported. Nevertheless, approaches based on limited germplasm diversity analysis (Zakhia et al., 1995) and the transgenic technology approach (Munyikwa, 1997) are currently being followed by distinct groups worldwide. Results from the germplasm diversity analysis have indicated an apparently low amylose content diversity, with values varying from $18 \%$ to $25 \%$, a strong environmental effect on amylose/amylopectin ratio in the accumulated starch, and cultivar dependence on the environmental effect during harvesting (Sriroth et al., 1999). Results from transgenic technology to generate mutant clones with antisense technology have indicated several limitations, including genetic background dependence to obtain success in regulation of a starch phenotype, an inefficient regeneration system of genetically transformed plants, a lack of stable character expression, and non-existent genetic analysis of the transformed population of cassava. Sequences for the genes coding for the enzymes ADPG-pyrophosphorilase (ADPGggase; Munyikwa, 1997), granule-bound starch synthase (GBSS; Salehuzzaman et al., 1993), and starch branching enzyme (SBE; Salehuzzaman et al., 1992) from cassava storage roots have been reported.

The present report shows previously unknown diversity in cassava with distinct starch structure and high free sugar accumulation in traditional clones. It also shows that the high free sugar and starch accumulation is cultivar dependent, and that the accumulation of free sugar is dependent on tissue age of the storage root with advanced secondary growth. In addition, the enzyme activity of ADPGppase and branching enzyme, as well as their identification by protein blot analysis, indicated a disruption in the biosynthesis of starch in cassava. Gene expression analysis of the gene coding for the major enzymes in this pathway indicated the lack of a transcript for the gene coding for branching enzyme, but not for ADPGppase.

\section{Materials and methods}

\section{Plant material}

Expeditions to the Amazon Basin visited different locations, interviewed farmers, and visited local market and rural communities to explore the diverse agricultural systems used for cassava in the search for rare clones of this crop. Field tests for starch and glucose levels in the storage root were performed with iodine solution and urine glucose strip tests to identify clones of interest. Stem cuttings were collected to build a clone collection in the greenhouse and in the field in EMBRAPA Genetic Resources and Biotechnology, Brasilia. Storage root samples from the field and greenhouse plants were used for further studies. Commercial cultivars and new clones are listed in tables and figures, depending on the experiment. 
Tissue sampling and preparation for carbohydrate analysis

Uniform 45-60 cm storage roots were selected, washed, and the root peel removed. A $10 \mathrm{~cm}$ central part of the storage root of $5 \mathrm{~cm}$ diameter was taken for all studies, and sampled differently, depending on the experimental objective. For clone comparison, in terms of sugar, enzyme activity and gene expression analyses, the whole section of the storage root was used. For the tissue age studies, the three tissue systems - tissue system I (layer 1, L1), tissue system II (layer 2, L2), and tissue system III (layer 3, L3; layer 4, L4; layer 5, L5) were sampled as previously reported (Cabral et al., 2000; Daiuto, 2000; de Souza, 2001). Sampled tissue layers were freeze-dried and stored at $-80{ }^{\circ} \mathrm{C}$ until use.

\section{Free sugar and polysaccharide extraction}

Tissue samples were ground to powder with liquid $\mathrm{N}_{2}$ with a pestle and mortar. A $5 \mathrm{~g}$ portion of the powders was used for carbohydrate extraction in $20 \mathrm{ml}$ of ethanol solution $(85 \%)$ in milliqui- $\mathrm{H}_{2} \mathrm{O}$ with three washes and centrifugation $(5000 \mathrm{rpm}$, $\left.15^{\circ} \mathrm{C}, 15 \mathrm{~min}\right)$. An ethanol/water solution from the pooled supernatants was used for sugar quantification, evaporating the ethanol solution to minimum volume by blowing $\mathrm{N}_{2}$ air in a dry evaporator at $50{ }^{\circ} \mathrm{C}$, with the final volume brought to $3 \mathrm{ml}$ with milliqui- $\mathrm{H}_{2} \mathrm{O}$. The resulting pellet was used for water-soluble $\alpha$-polyglucan and starch granule isolation and purification. The water-soluble $\alpha$-polyglucan was suspended in milliqui- $\mathrm{H}_{2} \mathrm{O}$ with two washings of the pellet and centrifugation (5000 rpm, $15^{\circ} \mathrm{C}, 15 \mathrm{~min}$ ). Starch granules were suspended in milliqui- $\mathrm{H}_{2} \mathrm{O}$ filtered through a $45 \mu \mathrm{m}$ glass filter and air dried. Two extractions were done and the carbohydrate analysis performed with three replications for each sample. The OD readings were taken in a microtiter plate (BioRad model 3550) or spectrophotometer (Hitachi, model U2000).

Free monosaccharide composition determined by gas chromatography of alditol acetates

Dried tissue from storage root of clones CAS36.1 and $\mathrm{cv}$. IAC 12-829 was ground to powder in liquid $\mathrm{N}_{2}$. A scoop of powder was added with $100 \mu \mathrm{l}$ double-distilled $\mathrm{H}_{2} \mathrm{O}$, sonicated (high for $5 \mathrm{~min}$ ), centrifuged (maximum speed microcentrifuge for 5 min at room temperature), supplemented with 3 volumes of 200 proof ethanol, and incubated at $20{ }^{\circ} \mathrm{C}$ for more than $1 \mathrm{~h}$ for extraction. Extracts were dried out in a speed vacuum and a pellet of $0.3 \mathrm{mg}(\mathrm{CAS} 36.1)$ and $0.01 \mathrm{mg}$ (IAC 12-829) were processed for monosaccharide composition identification by the alditol acetate procedure (Reiter et al., 1993) with myo-inositol $(1 \mathrm{mg} / \mathrm{ml})$ as internal standard for GC-MS identification of sugar and quantification.

\section{Glucose quantification}

The amount of glucose was estimated by the glucose oxidase isomerase microassay method adapted from Fox and Robyt (1991) with minor modifications. A standard curve was prepared with glucose (Sigma) in the concentration range of 1-20 mg/1 for linearity.

\section{Sucrose quantification}

The amount of sucrose was estimated according to Carvalho (1990). Sucrose quantity was estimated by subtracting the total glucose left by invertase hydrolysis from the free glucose estimated in the extracted solution as above.

\section{Total starch quantification}

Dried starch granules were used for total starch quantification with Starch Kit Assays (Sigma) with minor adaptations. Dilutions were carried out as necessary to fit into the linearity of the glucose standard curve. Potato starch (Sigma) was used as a standard adjusted to fit in the linearity range of the standard curve of glucose. The same procedure was used for soluble $\alpha$-polyglucan.

\section{Starch structure analysis}

Branched $\alpha$-polyglucans were solubilized in $0.1 \mathrm{M}$ $\mathrm{NaOH}$ as-needed, purified by size exclusion chromatography (Sepharose CL-2B) previously equilibrated with $0.1 \mathrm{M} \mathrm{NaOH}$ solution and with the iodine test for peak identification. Separated peaks were neutralized with $0.1 \mathrm{M}$ acetic acid, precipitated with ethanol, and the pellet collected with centrifugation. Purified $\alpha$-polyglucans (100 mg) 
were digested with isoamilase in sodium acetate buffer $(50 \mathrm{mM}$ sodium acetate $\mathrm{pH}$ 6.0). The resulting chain length fragments' distribution profiles were identified by their ionized mass in a matrix-assisted laser adsorptions/ionization timeof-flight mass spectrometry (MALDI-TOF) with a standard matrix for carbohydrate.

\section{Tissue sampling and preparation for enzyme} activities and protein analysis

Fresh storage root tissues were processed immediately by freezing in liquid $\mathrm{N}_{2}$ and stored at $-80{ }^{\circ} \mathrm{C}$ until used. All procedures were performed under ice-cold conditions with extraction buffer containing $50 \mathrm{mM}$ Tris- $\mathrm{HCl}$ pH $7.0,0.5 \mathrm{mM}$ EDTA, 2 mM DTT, 0.1\% BSA, $100 \mu$ M PMSF, $10 \mu \mathrm{M}$ chymostatin and $10 \mu \mathrm{M}$ leupeptin.

\section{Soluble proteins}

For protein quantification, aliquots of $50 \mu \mathrm{l}$ of protein extracts and standard BSA $(2 \mathrm{~g} / \mathrm{l})$ were added to $450 \mu \mathrm{l}$ double-distilled $\mathrm{H}_{2} \mathrm{O}, 100 \mu \mathrm{l}$ sodium deoxycholate $(0.15 \%)$ and $100 \mu \mathrm{l}$ of TCA (12\%), left to sit at room temperature for $10 \mathrm{~min}$ and spun for $10 \mathrm{~min}$ at $4{ }^{\circ} \mathrm{C}$. The collected pellet was suspended in $50 \mu \mathrm{l}$ of solubilizing reagent ( $5 \%$ SDS, $0.1 \mathrm{M} \mathrm{NaOH}$ ) and $1 \mathrm{ml}$ of BAC working reagent was added according to the BCA method procedure from Pierce (Micro BCA Protein Assay Kit).

\section{Activity of the enzymes involved in the starch synthesis}

Protein solutions for all enzyme assays were concentrated by reducing $20 \mathrm{ml}$ of the enzyme extract to $10 \mathrm{ml}$ with Biomax $30 \mathrm{~K}$ from Millipore with centrifugation $\left(3000 \mathrm{rpm}, 60 \mathrm{~min}, 4^{\circ} \mathrm{C}\right)$. All enzyme assays were previously tested for the range of linearity for a particular enzyme extraction by varying either volume of the crude extract or reaction time. All reported enzyme activities for the samples are within the linearity range for each particular enzyme.

\section{$A G D$ activity}

The AGD activity assay followed assay A described by Ballicora et al. (1998) with minor adaptations. Readings were taken in a Multipurpose Liquid Scintillation Counter (Beckman, model LS 6500) calibrated for a ${ }^{32} \mathrm{P}$ specific activity of $380 \mathrm{cpm} / \mathrm{nmol}$ of ${ }^{32} \mathrm{PPi}$. Enzyme activities are expressed as enzyme units $(\mathrm{EU}=\mathrm{nmol}$ ${ }^{32}$ P-ATP formed per minute) per milligram of protein.

\section{Soluble starch synthase (SSS) activity}

The enzyme activity assay followed assay B described by Macdonald and Preiss (1983) with minor adaptations. Readings were taken in a Multipurpose Liquid Scintillation Counter (Beckman, model LS 6500) calibrated for ADP $\left[{ }^{14} \mathrm{C}\right]$ glucose with a specific activity of $46.3 \mathrm{cpm} / \mathrm{nmol}$. Enzyme activities are expressed as enzyme units $\left(\mathrm{EU}=\mathrm{nmol}\left[{ }^{14} \mathrm{C}\right]\right.$ glucose incorporated per minute) per milligram of protein.

\section{Starch branching enzyme (SBE) activity}

The enzyme activity assay followed the assay described by Hawker et al. (1974) with minor adaptations. Readings were taken in a Multipurpose Liquid Scintillation Counter (Beckman, model LS 6500) calibrated for $\left[{ }^{14} \mathrm{C}\right]$ glucose-1-phosphate specific activity of $46.3 \mathrm{cpm} / \mathrm{nmol}$. Enzyme activities are expressed as enzyme units $(\mathrm{EU}=\mathrm{nmol}$ $\left[{ }^{14} \mathrm{C}\right]$ glucose incorporated per minute) per milligram of protein.

\section{SDS-PAGE and immunoblotting}

An equivalent amount of $20 \mu \mathrm{g}$ of protein was separated in pre-cast SDS-PAGE gel of $4-15 \%$ gradient and run. The gel was blotted onto a nitrocellulose membrane and incubated with rabbit antiserum against ADPG-pryrophosphorylase (GPase-Ab), SBEI (mSBEI-Ab), and SBEII (mSBEII-Ab) and the protein revealed with an alkaline phosphatase-conjugate goat antirabbit antiserum according to Ballicora et al. (1998).

cDNA synthesis and subtractive PCR from storage root of cassava

Total RNA was extracted from cassava plant storage roots as described by de Souza (2001). Polyadenylated RNA was purified from $500 \mu \mathrm{g}$ total RNA with the mRNA purification kit 
(Pharmacia). Double-stranded cDNAs were synthesized and subtractive PCR was conducted with the PCR-Select cDNA Subtraction Kit (Clontech). All procedure steps to obtain the subtracted cDNA were performed according to the manufacturer's protocol. In brief, Cas36.1 (tester) and IAC (driver) cDNAs were synthesized separately from $2 \mu \mathrm{g}$ of poly(A) ${ }^{+}$RNA. The tester and driver cDNAs were separately digested with $R s a \mathrm{I}$. The tester sample then was divided into two populations and each one ligated with adaptor 1 or $2 \mathrm{R}$. Each tester population was hybridized separately with excess driver cDNA (33-fold). The two hybridization reactions were combined (with additional driver cDNA) for a second subtractive hybridization. The hybridizations led to equalization and enrichment of differentially expressed sequences. Finally, the differentially expressed cDNAs were amplified by PCR and cloned into the pGEM-Teasy vector (Promega).

Amplification of ADPG, GBSS, branching enzyme, phosphoglucomutase and debranching enzyme cDNAs by PCR

Double-stranded cDNA from cv. IAC 12-829 obtained before was used as template in PCR amplification. The primers set used were ADPG (5'-TGGCGAGTATGGCGGCCATC- $3^{\prime}$ and $5^{\prime}$ GATCACGGTTCCGCTGGGAATC- ${ }^{\prime}$ ), GBSS (5'-TGCCTTCTCAGACTTCCCACG- $3^{\prime}$ and 5'-GACCACCAGTAGAGCAACAATGGG-3'), branching enzyme (5'-TATCGTGAGTGGGCTCCTGC- $3^{\prime}$ and $5^{\prime}$-TCCCATAGCTTATGGTAGCCTCG-3'), plastidic phosphoglumutase (5'-GTATTTGATGCCATGCATGC- $3^{\prime}$ and $5^{\prime}$-TTTCTATCACCATCTCCATC-3'), cytosolic phosphoglucomutase (5'-GCAAATGGAGTAAGACGTGT- $3^{\prime}$ and $5^{\prime}$-ACACCATGAAGTGCATCATA$\left.3^{\prime}\right)$ and isoamylase (5'-ATTGTTGGCCCCCAATGGC-3' and 5'-CACAATCCCATGCTTCAGC-3'). The amplification protocol consisted of one cycle at $94{ }^{\circ} \mathrm{C}$ for $5 \mathrm{~min}, 30$ cycles of $94^{\circ} \mathrm{C}$ for $1 \mathrm{~min}, 45^{\circ} \mathrm{C}$ for $1 \mathrm{~min}$ and $72{ }^{\circ} \mathrm{C}$ for $2 \mathrm{~min}$, and a final extension at $72{ }^{\circ} \mathrm{C}$ for $15 \mathrm{~min}$. The PCR products were cloned into the pGEM-Teasy vector (Promega) and sequenced. The clones obtained were named as pGEMcas4 for cytosolic and pGEMcas5 for plastidic phosphoglucomutase, pGEMcas6 for ADPG-pyrophosphorylase, pGEMcas8 for branching enzyme, pGEMcas7 for starch synthase, pGEMcas9 for isoamylase and were also used as probes in gene expression analysis.

\section{DNA sequencing and analysis}

Single bacterial colonies of the result of a previously prepared subtracted cDNA library were inoculated in 96-well microtiter plates containing LB and ampicillin $(100 \mathrm{mg} / \mathrm{l})$ and allowed to grow overnight with shaking at $37^{\circ} \mathrm{C}(18 \mathrm{~h}$ at $320 \mathrm{rpm})$. The DNA was purified by a standard alkaline lysis method with one modification at the end of the procedure, where the supernatant was passed through a multi-screen filter (Millipore) prior to DNA precipitation. The purified DNA was resuspended in water. The sequencing reactions were performed with $200 \mathrm{ng}$ of DNA according to standard protocols of the ThermoSequenase II dye terminator cycle sequencing kit (Amersham-Pharmacia Biotech) with universal M13 forward and reverse primers and the capillary sequencer MegaBACE 1000. The samples were electro-injected by $2 \mathrm{kV}$ for 100 and the fragments were separated at $9 \mathrm{kV}$ for $100 \mathrm{~min}$. The electropherograms were submitted to the Phred, Phrap \& Consed package for sequence quality evaluation. The sequences with Phred $>20$ were automatically blasted against NCBI GenBank, the clone with insert for the sucrose synthase gene (pGEMcas3) was identified and used as probe in gene expression analysis.

\section{Results}

\section{Phenotype isolation in the field}

The iodine starch field test and the glucose oxidase-peroxidase strip test applied to the crosssection of the storage root of cassava showed a diverse presence of starch distribution and the occurrence of glucose in traditional clones of cassava (Figure 1). The cross-section of storage root of a farina type of cassava (panel A1) cv. IAC 12829 showed the stained starch color across the whole area, but no presence of glucose (panel B1). In contrast, the traditional clone CAS36.1 showed no dark-blue starch color (panel A2) but glucose presence (panel B2) at a high level. In clone CAS36.0 starch is present within parenchyma cells 


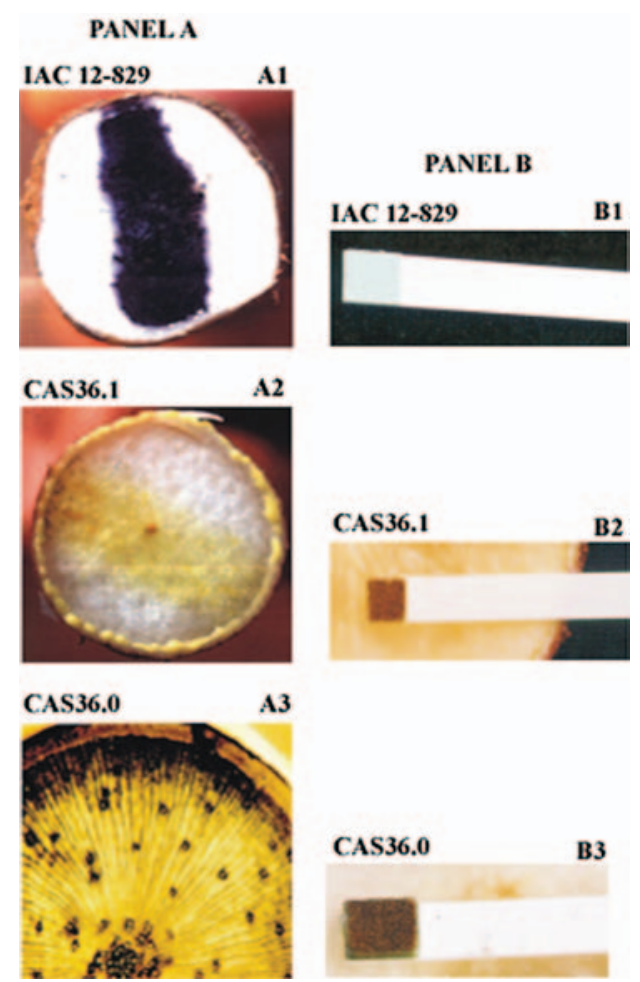

Figure 1. Diversity of storage root identified on the field expedition to the center of origin and domestication in the Brazilian Amazon. (Panel A) Field iodine test for the dark blue color in the cross-section of the storage root for the presence of starch is shown in panel A. (Panel B) Field glucose oxidase-peroxidase strip test for the brown color for the presence of glucose. A large variation in the pattern of starch accumulation is observed in different parts of the root. Each close-up corresponds to a picture of a single representative storage root out of more than 60 roots tested in the field.

surrounding the secondary xylem vessels (panel A3) and within parenchyma cells in early developmental stages close to the cambium. Glucose is present in high amounts (panel B3) as well. Stem cuttings of 27 traditional clones were collected, organized in a GenBank collection, and planted in an environment outside the Amazon region, to observe the root and developmental factors responsible for these phenotypes obtained in the field trip.

\section{Sucrose, glucose and starch content diversity in clones}

To gain knowledge of the genetics of this clones in a different environment from the Amazon region, the 27 traditional clones were cultivated in the field facilities at EMBRAPA Genetic Resources and Biotechnology in Brasilia (Cerrado vegetation), an environment with a well-defined cold dry season, quite different from the Amazon region, which has no such season. Five traditional clones, out of the 27 identified in the field trip described above, were evaluated for their sugar and polysaccharide content and are shown in Table 1.

A new class of cassava storage roots, with high free sugar and low starch content, was revealed in addition to the typical farina and table cassava types. Glucose was the major free sugar accumulated in the traditional clone, with content values up to $22.5 \%$ on dry matter base for clone CAS36.1 and $0.08 \%$ for cv. IAC $12-829$, a farina-type cassava. Sucrose content values varied from $9.0 \%$ in the traditional clone CAS36.1 down to $0.02 \%$ in cv. IAC 12-829.

In accordance with this observation, the starch content values (Table 1) showed the opposite pattern and varied from $6.9 \%$ in the traditional clone CAS36.1, up to $69.3 \%$ (cv. Maniçobeira) on dry matter base. Similar values for free sugar and starch content in the farina and table-type cassava (O'Hair, 1989; Sarmento, 1997) has been reported 
Table 1. Storage root content $(\mathrm{mg} / \mathrm{g}$ dry weight) of glucose, sucrose, and glucose equivalent starch in the storage root of farina, table, and sugary cassava types.

\begin{tabular}{lllll}
\hline $\begin{array}{l}\text { Clone/ } \\
\text { cultivar }\end{array}$ & $\begin{array}{l}\text { Cassava } \\
\text { type }\end{array}$ & Glucose & Sucrose & $\begin{array}{l}\text { Glucose equi- } \\
\text { valent starch }\end{array}$ \\
\hline IAC 12-829 & Farina & 0.78 & 0.16 & 599.91 \\
& & $(0.01)$ & $(0.008)$ & $(66.07)$ \\
Manicobeira & Table & 2.09 & 31.77 & 693.34 \\
& & $(0.06)$ & $(1.42)$ & $(14.66)$ \\
CAS36.1 & Sugary & 224.70 & 90.01 & 69.33 \\
& & $(3.70)$ & $(13.72)$ & $(5.85)$ \\
CAS36.3 & Sugary & 152.37 & 49.16 & 263.31 \\
& & $(3.52)$ & $(12.80)$ & $(14.03)$ \\
CAS36.0 & Sugary & 158.20 & 72.68 & 232.69 \\
& & $(0.70)$ & $(7.03)$ & $(6.25)$ \\
\hline
\end{tabular}

Mean values are from a twice-replicated extraction and triplicate quantification. Standard deviation of the means is shown in parenthesis.

and is in the range of values reported here. However, there are no reports on the traditional cassava clones.

Such values are unusual for cassava storage roots and are reported here for the first time. Therefore we classified these new clones high in free sugar as sugary cassava, as distinct from the sweet (table type) and bitter (farina type) cassava commonly known in Brazil (Fukuda et al., 1996; Sarmento, 1997). Further studies were performed with the most unusual sugary clone as to free sugar content, CAS36.1, to better understand the developmental, biochemical and genetic mechanisms responsible for this type of storage root phenotype.

Monosaccharide composition, free sugar and starch distribution in tissue of the storage root

The effects of tissue age on the free sugar and starch pattern distribution in a sugary clone storage root with advanced secondary growth were evaluated. For this, uniform storage root size and identical storage root region were used to dissect tissue layers comprising a distinct tissue systems, as described in Materials and methods. The pattern of starch deposition observed in Figure 1 indicated an unusual distribution of starch in the storage root of the rare sugary clones.

A closer quantification of this pattern is shown in Figure 2. The distribution of glucose (Figure $2 \mathrm{~A}$ ), sucrose (Figure 2B) and $\alpha$-polyglucan
(Figure 2C) content in the different tissue layers varied among the types of cassava and was closely associated with the physiology of tissue system II and with the tissue age in tissue system III. The glucose content (Figure 2A) is low in layers corresponding to tissue systems $\mathrm{I}$ and II in all the cassava types. However, for tissue system III the glucose content was always high in the sugary cassava type as compared to farina and table cassava. This unusual distribution of glucose in the sugary cassava type is also variable in terms of tissue layers L3-L5. While glucose content decreases in the case of farina and table cassava types, this trend is not observed in the sugary cassava type. Values varied from $29.2 \%$, on a dry matter basis, in CAS36.1 (L4) down to $0.03-0.04 \%$ (L5) in the table and farina cassava types. These values are in the range for reported glucose content in storage root of table and farina type (O'Hair, 1989), no reports were found for the sugary clones.

The estimation of sucrose content derived by subtracting total glucose after sucrose hydrolysis with invertase (Figure 2B) showed variable trend in the distribution of this sugar in the tissue layers. Values of up to $16 \%$ (sugary clone CAS36.1) in L1 (tissue system I), and 14\% in L2 (tissue system II) for sugary clone CAS36.3 were observed. We also observed a trend of decreasing sucrose content towards the center of the central cylinder. This observation is consistent with the presence outside phloem in tissue system II (L2). This decreasing sucrose content pattern was similar in all types of cassava tested, including sugary, farina and table cassava. The sucrose content values reported for table and farina cassava types (Daiuto, 2000) are in the range for similar cassava types shown in this study. In the case of sugary cassava, the values are shown for the first time in the present study.

The distribution of starch accumulation varied according by type of cassava and tissue system. While starch content showed low values of accumulation in tissue systems I and II, in tissue system III this value is very high in the farina and table cassava types. Tissue system III is the core tissue of the central cylinder of the storage root for the accumulation of starch, reaching values of up to 69.3\% (L4 for Manicobeira), on a dry weight basis, and it is not detected in L5 of sugary clone CAS36.1. An unusual distribution of starch in the sugary cassava type is also variable in terms of 

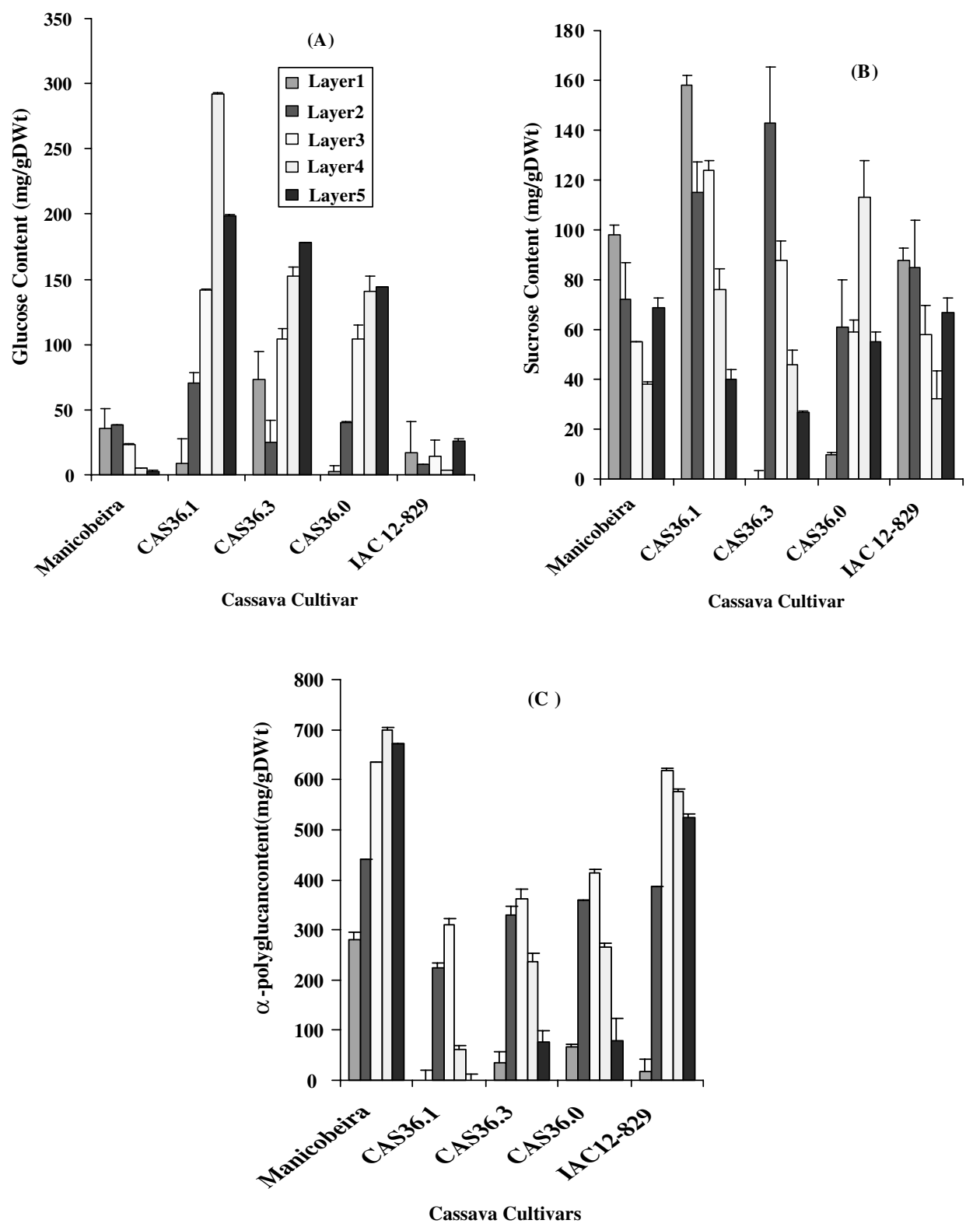

Figure 2. Distribution of glucose (A), sucrose (B), and $\alpha$-polyglucan (C) content in the tissue layers of a cross-section of a storage root of uniform size and diameter in the three cassava types, i.e. farina type (cv. IAC 12-829), table type (clone Manicobeira), and sugary type (CAS36.1, CAS36.6 and CAS36.0). Layers 1 and 2 correspond to tissue system I and II respectively. Layers 3, 4, and 5 correspond to cell zones of secondary xylem (tissue system III) with parenchyma cells of increasing age from layer 3 to layer 5. For details, see Materials and methods. Mean values were obtained from two extractions and triplicate measurements. The bars display the standard deviation from the mean for each sample.

tissue layers L3-L5 in tissue system III. There is an increase in starch content from L1 to L3 up to $30 \%$ followed by a drastic decrease down to an undetectable value in sugary clone CAS36.1. Similar values for starch content in intact storage root and tissues have been reported for farina and table cassava types (O'Hair, 1989; Sarmento, 1997, Daiuto, 2000) but not for the sugary clones reported here.

The unusual developmental pattern observed in the sugary clones, based on tissue age of storage root with advanced secondary growth, was further 
studied in terms of monosaccharide composition by gas chromatography of alditol acetates. The question is intriguing how old tissues (L4 and L5) that commonly accumulate the osmotic inactive starch, can start to accumulate a very high osmotic active component such as glucose?

This question was dealt with by analyzing monosaccharide composition in clone CAS36.1 in comparison with clone IAC12-829. Thus, we gained knowledge on the degradation of the cell wall as an indication of whether the cells need to expand during the loosening process to increase turgidity due to the accumulation of glucose. Several distinct sugars that accumulate in the sugary CAS36.1, but not in farina type IAC 12-829, are shown in Table 2. The main free sugar present in the water-soluble fraction in both cassava types is glucose. While several other free sugars are present in both types of cassava, sugars such as glucuronic acid, galacturonic acid and mannose are present only in CAS36.1. It is well known that these sugars are a component of the cross-linking glycans of the primary cell walls of the parenchyma cells (Reiter et al., 1999) of flowering plants. Therefore, the presence of these sugars in the water-soluble fraction in the clone CAS36.1 indicates the degradation of the parenchyma cell walls during the process of their adjustment for the accumulation of high free glucose.

\section{Starch structure diversity in clones}

The structure of the starch accumulated in the sugary cassava type was evaluated on the basis of color development of the starch-iodine complex

Table 2. Sugar composition of the water-soluble fraction of storage root of farina (IAC 12-829) and sugary (CAS36.1) cassava types.

\begin{tabular}{lll}
\hline Sugar type & IAC 12-829 & CAS36.1 \\
\hline Arabinose & 6 & 16.9 \\
Rhamnose & 4.2 & 4.9 \\
Xylose & 0.8 & 1 \\
Glucuronic acid & & 3.6 \\
Galacturonic acid & & 1.5 \\
Mannose & & 1.6 \\
Galactose & 12.9 & 21.7 \\
Glucose & 76.1 & 48.8 \\
\hline
\end{tabular}

Sugar identification and quantification $(\% \mathrm{~mol} / \mathrm{mol}$ of the fraction) are from the profile of a GSMS spectrum. and fragment analysis of the digested branched $\alpha$ polyglucan. The absorbance spectrum of the iodine-starch complex (not shown) indicated three kinds of starch in the clones analyzed. The first is the normal starch (cv. Maniçobeira) with a $\lambda_{\max }$ value of $595 \mathrm{~nm}$, corresponding to starch containing amylose and amylopectin polyglucan. The second is the clones CAS36.3 with $\lambda_{\max } 550 \mathrm{~nm}$ corresponding to amylose-free starch. Third is the clone CAS36.1 with $\lambda_{\max } 470 \mathrm{~nm}$ corresponding to an unusual starch composed of $\alpha$-polyglucan similar to glycogen $\left(\lambda_{\max }=450 \mathrm{~nm}\right)$.

Figure 3 displays the MALDI-TOF spectrum for isoamylase digestion of branched $\alpha$-polyglucan from the table cassava type (Figure 3A) and water-soluble $\alpha$-polyglucan from sugary clone CAS36.1 (Figure 3B). The chain length of $\alpha$ polyglucan from CAS36.1 spans from an ionize mass of 653 , equivalent to 3 units of glucose, to a maximum ionized mass of 1949 , which is equivalent to 11 units of glucose. For the case of the table type cv. Manicobeira, the chain length for the amylopectin spans from 1321 to 5518; this is equivalent to 7-40 units of glucose. These values are equivalent to the degree of polymerization observed in cassava tapioca as determined by Dionex techniques or conventional improved electrophoresis (McNeil et al., 1982; Hizukuri, 1985 , 1986) with values of $17-72$ glucose units.

Overall, the storage root of clone CAS36.1, in addition to accumulating a high level of free sugar in a variety of forms, but mainly as glucose, also carries an unusual starch structure. This is of importance for cassava as well as for science in general because of the type of storage organ in which it occurs and the contribution to our understanding starch granule formation.

\section{Enzyme activities and protein blot analyses}

Table 3 shows the activities of the three major enzymes of the starch synthesis pathway in the storage root of cassava. Overall, the activities for ADPGppase, soluble starch synthase, and SBE are high in the farina and table types of cassava, but very low in the sugary cassava type. Only residual activities for all the three enzymes are observed in CAS36.1, while in the other sugary cassava types (CAS36.0 and CAS36.3) they are 26-32\%, 22-64\% and $63-64 \%$ of the maximum activities for ADPGppase, soluble starch synthase and SBE in the 

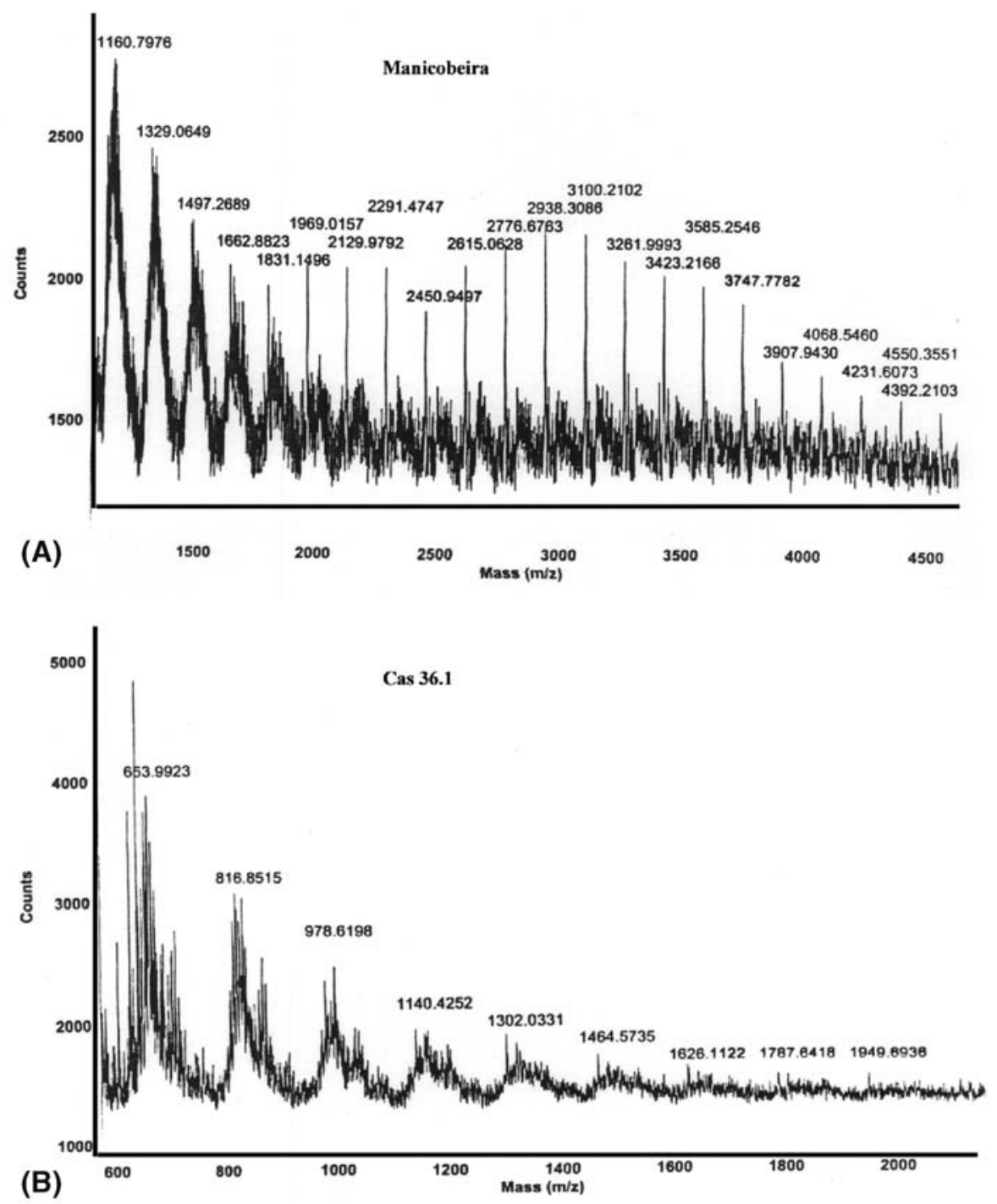

Figure 3. MALDI-TOF ionized mass spectrum of branched $\alpha$-polyglucan from table cassava (A, top, Manicobeira) and sugary cassava (B, bottom, CAS36.1) in size exclusion chromatography after fragmentation by digestion with isoamylase. Values displayed are the mass of fragments corresponding to the equivalent number of glucose units in the particular fragment from a single experiment run.

known cassavas, respectively. The values observed for the farina type are in the range observed for cassava storage root (Daiuto, 2000), but there are no results for the sugary type. These results strongly suggest a disruption in the starch synthesis pathway in the sugary cassava and a possible mutation in the CAS36.1 clone.

Figure 4 shows protein separation in SDSPAGE (Figure 4A) and blot analysis (Figure 4B) probed with antibody GPase-Ab against ADPG pyrophosphorylase as well as mSBEI-Ab and
mSBEII-Ab antibodies against soluble SBE isoforms I and II from maize. The enzyme protein of equivalent size to SBE isoform I (Figure 4B(a)) was displayed with the antibody against the maize branching enzyme (mSBEI-Ab) in all clones studied, except for clone CAS36.1. For SBE isoform II, the antibody against the maize isoform II $(\mathrm{mSBEII}-\mathrm{Ab})$ recognized a protein of higher molecular mass than the maize positive control (Figure $4 \mathrm{~B}(\mathrm{~b})$ ) in the cassava clones studied, except for clone CAS36.1. A similar pattern of en- 
Table 3. Starch enzyme activities (nmol/min per mg protein) for the storage root of farina, table, and sugary cassava.

\begin{tabular}{lllll}
\hline $\begin{array}{l}\text { Clone/ } \\
\text { cultivar }\end{array}$ & $\begin{array}{l}\text { Cassava } \\
\text { type }\end{array}$ & $\begin{array}{l}\text { AD- } \\
\text { PGppase }\end{array}$ & $\begin{array}{l}\text { Soluble } \\
\text { starch } \\
\text { synthase }\end{array}$ & $\begin{array}{l}\text { Branching } \\
\text { enzyme }\end{array}$ \\
\hline IAC 12-829 & Farina & 8005 & 199360 & 463411 \\
Manicobeira & Table & 63895 & 201354 & 426125 \\
CAS 36.1 & Sugary & 1615 & 3493 & 2202 \\
CAS 36.3 & Sugary & 23791 & 42757 & 280081 \\
CAS 36.0 & Sugary & 19983 & 127404 & 283629 \\
\hline
\end{tabular}

Mean values from a single extraction with two replicate measurements of the radioactive assays for each enzyme are shown. In all assays, the formation of reaction product was linear with time and with the amount of added enzyme preparation.

zyme protein recognition was also observed with ADPGppase which was recognized by antibody against the small subunit of this enzyme from spinach (Gpase-Ab) in all clones of cassava tested, except sugary clone CAS36.1 (Figure 4B(c)).

\section{Gene expression analysis}

The sucrose-starch conversion pathway was simplified and aligned by RNA blot analysis to observe gene expression at the level of transcript and to gain knowledge at the molecular level of the regulation of unusual starch synthesis in clone
CAS36.1. Figure 5 displays the analytical results for several candidate genes in this pathway that could help to explain the starch phenotype in the sugary and farina cassava types. ADPGppase and branching enzyme turned out to be important candidates for the missing gene expression in protein blot analysis.

However, the corresponding mRNA for ADPGppase protein hybridized, in both clones, with a cDNA probe (pGEMcas6) that had been cloned and sequenced and had its identity confirmed to $96 \%$ with the gene coding for the small subunit of ADPGppase from cassava reported by Munyikwa (1997). A cDNA fragment derived from a cDNA population obtained from the storage root of IAC 12-829, which was cloned and sequenced, and had its identity confirmed to $98 \%$ of branching enzyme reported for cassava (Salehuzzaman et al., 1992), was used as a probe in the present study. The results displayed in Figure 5 indicate that the gene coding for the branching enzyme from cassava is expressed in cv. IAC 12-829, but not in sugary clone CAS36.1.

\section{Discussion}

This study presents a new class of cassava storage root showing unusual traits that are dramatically different to those of the common farina and table

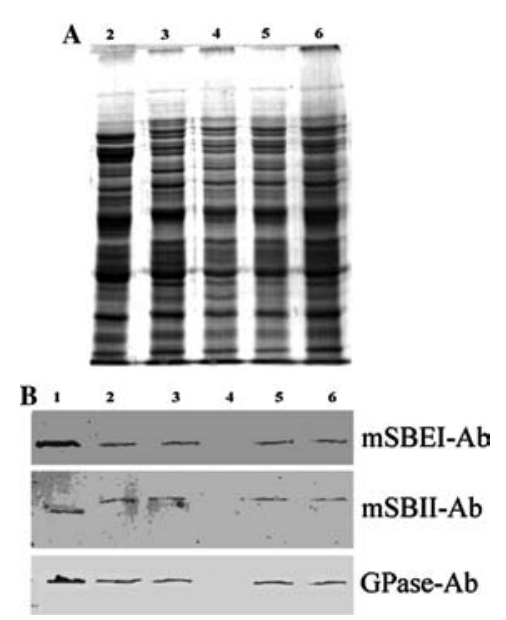

Figure 4. (A) Soluble protein extracts from farina cassava (lane 2, IAC 12-829), table cassava (lane 3, Manicobeira), and sugary cassava (lane 4, CAS36.1; lane 5, CAS36.0; lave 7, CAS36.3) separated in SDS-polyacrylamide gel electrophoresis (gradient gel of 7$15 \%$ ) and its corresponding blot probed with antibodies against three enzyme proteins of the starch synthesis pathway. (B) The corresponding protein blot probed with ADPGase-Ab against small-subunit, mSBEI-Ab against branching enzyme isoform I, and mSBEII-Ab against branching enzyme isoform II. The positive control (lane 1) for each specific antibody is also displayed. For details, see Materials and methods. 


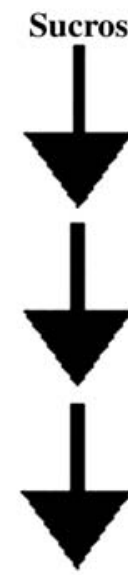

Glocose-1-P

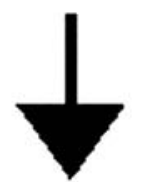

ADP-Glucose

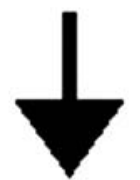

1,4- $\alpha$-D-glucan

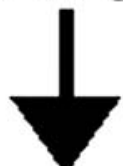

Sucrose Synthase

Phospho glucomutase.pm

Phospho glucomutase.cyt
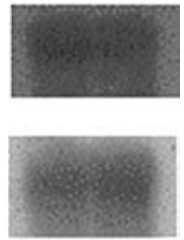

ADPG-pyrophosphorilase

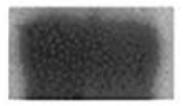

Starch Synthase

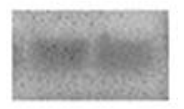

Branching enzyme
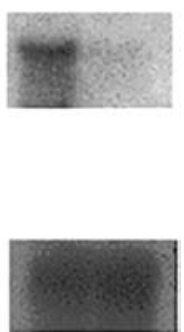

Isoamilase

1,6- $\alpha$-D-(1,4- $\alpha$-D-glucano)-glucan

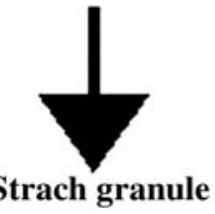

Figure 5. Gene expression analysis for the gene coding for starch enzyme proteins in farina cassava (IAC 12-829) and sugary cassava (CAS36.1). The results of the mRNA blots were aligned with the metabolic steps in which each gene product is catalyzed in a simplified starch pathway. In all autoradiographs, the left lane is the farina cassava (Far.); the right lane is the sugary cassava (Cas.). See Materials and methods for details on the cDNA probe generated and used.

cassava types. These differences are reported here in terms of biochemical characteristics, tissue age effect, and at the molecular level of starch structure and gene expression. This new class of cassava storage root was named sugary cassava because of its high free sugar content.

A distinct starch structure was identified in clone CAS36.1 of this sugary class of cassava. A disruption in the starch biosynthesis pathway was identified in the clone CAS36.1 as evidenced by enzyme activity evaluation and protein blot analysis. Two developmental processes related to tissue differentiation were identified among the types of cassava studied. At the molecular level, the gene expression analysis for the major starch synthesis enzyme proteins revealed the missing expression, 
at the level of protein and mRNA, for the starchbranching enzyme gene previously isolated from cassava.

\section{Diversity of free sugar content and starch structure in traditional clones from the Amazon}

The results from the field collection revealed unusual traits in the storage root that have not been reported before. Bearing in mind that the field trip was directed to look for diversity in the storage root of cassava, this previously undiscovered diversity may be because most other germplasm collection around the world has been oriented to look for diversity of accession with a high dry matter yield and a high starch content.

In addition, a large variation in starch distribution pattern within the storage root was also observed, closely associated with age of the storage root tissue of the core starch storage tissue system. Again, this observation may be explained by the fact that most cassava studies have not considered the development of tissue in advanced secondary growth, and the storage root has been sampled as a whole root.

The phenotype of these traits was the same when the clones were cultivated in the Cerrado region outside Amazonian environmental and climatic conditions. These observations confirmed the initial assumption that this trait is, somehow, genetically fixed in these clones because of the vegetative propagation nature of cassava. However, further genetic studies are needed to establish the number of genes involved in this trait, as well as to understand its inheritance and where it is mapped in the cassava genome. These results are paralleled by the description of a cassava type with a high water content reported in the 16th century (Travaço, 1596), and more recently by the description of germplasm collection of cassava with a very low starch content in Amazon (de Albuquerque, 1969). The occurrence of this diversity in the Amazon region opens a new avenue of research in the field of starch synthesis and accumulation in the cassava storage root.

This study also reveals a novel (sugary) cassava type, gained from traditional clones, in which the high free sugar (mainly glucose) content is closely associated to storage root development, as discussed below. A novel starch structure was shown to be present within this sugary cassava type. This novel starch displays a similar structural property to glycogen from mammals and is clone-dependent. This result indicates a disruption in the starch pathway in clone CAS36.1 that may be genetically related to the missing expression of the gene coding for SBE as discussed below.

\section{Developmental aspects of starch and free sugar accumulation}

The results obtained by dissecting tissue layers of cassava storage root with advanced secondary growth revealed two different patterns of accumulation of starch and free sugar, depending on cassava type. They also showed that the distribution patterns of starch and free sugar may be related to two different developmental processes. In the case of farina and table cassava types, the accumulation of starch and the content of free sugar were in accordance with the physiology of tissue system II and tissue age in tissue system III. However, in the sugary cassava type, the pattern of starch accumulation and free sugar showed the same pattern for tissue system II, but an unusual pattern in tissue system III. In our laboratory, we have based our developmental studies of the storage root of cassava using advanced secondary growth root in the identification of tissue types and the description of their anatomy to study its effect on their composition (Rateaver, 1951; Cabral et al., 2000; Daiuto, 2000; de Souza, 2001). Shortly, tissue system I (layer I, L1), tissue system II (layer 2, L2) and tissue system III (layer 3, L3; layer 4, L4; layer 5, L5) have been established as three compartments of the storage root (Cabral et al., 2000; Daiuto, 2000; de Souza, 2001). In tissue system II, which comprises the outside phloem and cambium, we were able to explain the distribution of starch and free sugar content among all studied clones based on the physiology of their tissue cell constituent. The high sucrose content in L2 is consistent with the long-distance sucrose transport function of the phloem and its direct connection with parenchyma storage cells in tissue system III. The high glucose content in L3 indicates very high activity of sucrose breakdown enzyme in tissue system III, accounting for unloading of sucrose from the phloem into tissue system III (secondary xylem) and its highly starch accumulating specialized parenchyma cells for all type of cassava. Tissue system III (i.e. the central cylinder of the storage root) is of particular 
importance because it comprises the major parenchyma storage cells where the accumulation of starch occurs, and it is the edible part of the storage root. This tissue system is the inner tissue derived from the cambium's activity as the adventitious root swells (Rateaver, 1951), and it is thus possible to recognize parenchyma storage cells at different ages as they progressively arise from the outer cambia meristem and differentiate to the inner diameter of this tissue system. Therefore, tissue layers in tissue system III were hand-dissected in cell zones and named L3 (youngest parenchyma cells), L4 (intermediately aged parenchyma cells) and, finally, L5 (old parenchyma cells attached to primary xylem). These layers have been shown to be composed of $86 \%, 74 \%$, and $48 \%$ of parenchyma cells, respectively, for L3, L4, and L5 (de Souza, 2001). They were used, therefore, to explain the distinct pattern of starch and free sugar distribution among the three classes of cassava in the present study.

While in the farina and table types of cassava, the accumulation and distribution of starch and free sugar content follow the normal development of tissue age, the sugary cassava showed an unusual developmental pattern by accumulating high glucose in L4 and L5 of tissue system III. This pattern rose the question of what changes must take place in the parenchyma cells in order for high osmotic active glucose to accumulate instead of osmotic inactive starch (accumulated in the early parenchyma cells as root diameter increased). One change that could account for the high glucose content may be hydrolysis of starch either by the phosphorylytic degradation mechanism or by the cleavage of starch by a series of starch hydrolytic enzymes, as happens during seed germination in cereals, or by both.

Although this study does not allow to concluding which pathway is present, we consider the phosphorylytic mechanism to be a strong candidate. This is based on the coincidence of the complete disintegration of the amyloplast in that tissue (preliminary observation not shown). In this case, the isozymes of starch phosphorylase and their occurrence in the cytosol or plastid are the target enzyme to be studied. The other change required for this adjustment is degradation of the cell wall of the parenchyma cells to allow these cells to become turgid due to the osmotic effect of the high glucose content.
These hypotheses hold true based on the observation of monosaccharide composition of the storage root of sugary cassava clone (CAS36.1) in comparison to the farina cassava type (cv. IAC 12829). The presence of mannose, galacturonic acid and galacturonic acid in the water-soluble fraction of the sugary but not of the farina cassava indicate that the cross-linking glycan (i.e. hemicellulose) polysaccharide, a component of the primary cell wall of the parenchyma cells, has degraded in CAS36.1. Therefore, a process developmentally distinct from that in farina and table cassava did take place in the layers of tissue system III of sugary cassava. This process involves disassembling the cell walls of the parenchyma cells and corroborates the notion of a differential distribution pattern of starch and the high glucose content in the sugary cassava. It is also possible that other factors change to varying extents the needs for high glucose accumulation in the tissue system III. For example, the level of free sugar content may also be modulated by environmental factors that were not studied here. Thus, further studies will be needed to test to which extend the level of free sugar is affected, especially by water availability.

\section{Enzyme activity and protein blot variation among classes of cassava}

The data presented in this paper show a profound effect of the high-free-sugar clone phenotype on the three major starch synthesis enzymes, in addition to variation in the recognition of their corresponding proteins by specific antibodies.

Activities for ADPGppase, soluble starch synthase, and SBE were always higher for the farina and table cassava types than for the sugary type. Of especial interest was the clone CAS36.1 because of the trace enzyme activity observed in the three enzymes evaluated (Table 3 ), the missing crossreactivity of its corresponding protein with the three antibodies tested (Figure 4), the missing expression of the gene coding for SBE (discussed below) and the change in structure (Figure 3) of the product of the starch biosynthesis pathway.

Attempts to identify the molecular mechanism responsible for other sugary clones with distinct starch phenotypes are currently being researched and will be the subject of a subsequent paper, including CAS36.0 and CAS36.3, which showed an amylose-free starch (results not shown). These 
results may have several explanations, including enzyme isoform interaction of a particular step in the pathway, pleiotropic effects among the enzyme activities during the synthesis of amylose and amylopectin, missing gene expression of a specific enzyme isoform in the pathway, and developmental changes in the tissue of the parenchyma storage cells during storage root secondary growth. These possibilities are the subject of our current research.

\section{Levels of enzyme protein transcript differences between CAS36.1 and IAC 12-829}

We sought the missing gene expression for the enzyme protein in the starch synthesis pathway, using the available tools in our laboratory. This study indicated that the expression of several genes was similarly present in both IAC 12-829 and CAS36.1, except in the gene coding for the branching enzyme. The expression of the gene coding for sucrose synthase protein was included to test the possibility that this gene would drive sucrose cleavage via the UDPglucose pathway, which would serve as the substrate for the UDPGppase in its production of glucose-1-phosphate to gain the glycogen pathway. However, mRNA hybridization blot analysis with a cDNA clone (pGEMcas3), derived from our subtractive cDNA library, showed that expression of this gene was present in both clones tested. Therefore, this possibility could be eliminated. The gene coding for two isozymes (cytosolic clone cGEMcas4 and plastidic clone pGEMcas5) of phosphoglucomutase was also tested for the occurrence of a starch-less phenotype (Alison M. Smith, e-mail communication). The results, however, showed the expression of those two genes in both clones tested. Again, this possibility could also be discounted. Another candidate for missing gene expression was taken from the results of protein blot analysis in this study (Figure 4), in which the small subunit protein for the ADPGppase did not cross-react with the $\mathrm{Ab}$ raised against the small subunit of leaf spinach protein. A cDNA clone was obtained based on previous reported gene sequence for the ADPGppase from cassava (Munyikwa, 1997) and used as a cDNA probe. The results indicated that this gene is expressed in both clones tested. Again, this hypothesis was not correct but emerged with the possibility that the protein had somehow gone missing from the tissue. This might have occurred either during the extraction by degradation or by a post-translation regulation or modification that could have disrupted its enzymatic function or its recognition by the antibody under in vitro conditions.

Because of the available tools in our laboratory and the high homology among the forms of the starch synthase we used a cloned cDNA fragment from the GBSS gene previously isolated from cassava (Munyikwa, 1997) as the mean to analyze the expression of the starch synthase responsible for step in the pathway leading the production of linear $\alpha-1,4$ glucan polymer. The expression of this gene was present in both cassava clones and was not related to the starch phenotype of clone CAS36.1.

The debranching enzyme has been genetically shown to play a major role in starch granule assembly. When the activity of this enzyme is missing in starch storage tissue there is a change in the balance of amylopectin and glycogen accumulation. We cloned a cDNA fragment for the gene of the isoamylase type of debranching enzyme and used it as a probe to analyze the expression of this gene. The results again showed the presence of the mRNA coding for this enzyme protein in both clones. It indicates that in cassava this possibility does not hold true for the accumulation of a glycogen-like polymer.

Finally, and somewhat unexpectedly, the expression of the gene coding for the cassava branching enzyme, achieved with a cDNA probe derived from a previously known gene sequence (Salehuzzaman et al., 1992) indicated that this gene is not expressed at a detectable level in clone CAS36.1. On the basis of these results we suggest that the missing expression contributes greatly to the kind of starch accumulated in CAS36.1.

\section{Acknowledgements}

We thank Dr Jack Preiss and his collaborator Mr. Kim Binderup (Department of Biochemistry MSU) for technical assistance in enzyme and protein blot analysis, and the scientific staff of the Complex Carbohydrate Research Center (UGa) for technical assistance in carbohydrate composition analysis. 
Our research was financed by the Rockefeller Foundation (RF96010\#25/RF9707\#26), Conselho Nacional Desenvolvimento Cientifico \& Tecnologico CNPq (45 2714-98.2), Programa Nacional em Biotecnologia CENARGEN (Project 060302058), and Cassava Biotechnology Network (small grant to L.J.C.B.C.).

\section{References}

Allem, A.C. 1994. The origin of Manihot esculenta Crantz (Euphorbiaceae). Genet. Res. Crop Evol. 41: 133-150.

Ball, S., Guan, H.P., James, M., Myers, P., Mouille, G., Buleons, A., Colonna, P. and Preiss, J. 1996. From glycogen to amylopectin: a model for the biogenesis of the plant starch granule. Cell 86: 349-352.

Ballicora, M.A., Fu, Y., Nesbitt, N.M. and Preiss, J. 1998. ADP-glucose pyrophosphorylase from potato tubers. Sitedirected mutagenesis studies of the regulatory sites. Plant Physiol. 118: 265-274.

Bogracheva, T.Y., Morris, V. J., Ring, S.G. and Hedley, C.L. 1998. The granular structure of C-type pea starch and its role in gelatinization. Biopolymers 45: 323-332.

Cabral, G.B., Carvalho, L.J.C.B. and Schaal, B.A. 2000. The formation of storage roots in cassava. In: L.J.C.B. Carvalho, A.M. Thro and A.D. Vilarinhos (Eds.) Cassava Biotechnology, Proceedings of the IV International Scientific Meeting CBN (3-7 November 1998, Salvador, BA, Brazil), EMBRAPA-Genetic Resources and Biotechnology Brasilia-DF, Brazil, pp. 345-356.

Carvalho, L.J.C.B. 1990. Maize acid invertases: purification, characterization, localization and function. Ph.D. Thesis, Cornell University, Ithaca, NY.

Carvalho, L.J.C.B., Cabral, G.B. and Campos, L. 2000. Raiz de reserva de mandioca: um sistema biológico de múltiplas utilidade. EMBRAPA-Recursos Genéticos e Biotecnologia. Serie Documentos 44. 16 pp. Brasilia, DF, Brazil.

Craig, J., Lloyd, J.R., Tomlinson, K., Barber, L., Edwards, A., Wang, T.L., Martin, C., Hedley, C.L. and Smith, A.M. 1998. Mutations in the gene encoding starch synthase II profoundly alter amylopectin structure in pea embryos. Plant Cell 10: 413-426.

da Cunha, A.G. 1978. Dicionário Histórico das Palavras Portuguesas de Origem Tupi. Companhia Melhoramentos, Universidade de Brasília, Brasília, Brasil, 357 pp.

Daiuto, E.R. 2000. Biosintese de amido durante o crescimento secundario da raiz de reserva da mandioca. M.Sc. Dissertation, Universidade Estadual de São Paulo, Botucatu-SP, Brazil.

de Albuquerque, M. 1969. A mandioca na Amazônia. SUDAM, Belém-PA, Brasil, 277 pp.

de Souza, CRB. 2001. Isolamento e caracterização molecular de genes e proteínas de raiz de reserva de mandioca (Manihot esculenta Crantz). Ph.D. Dissertation, Universidade de Brasilia, Brazil.

Edwards, A., Fulton, D.C., Hylton, C.M., Jobling, S.A., Gidley, M., Rossner, U., Martin, C. and Smith, A.M. 1999. A combined reduction in activity of starch synthase II and III of potato has novel effects on the starch of tubers. Plant J. 17: 251-261.

Fox, J.D. and Robyt, J.R. 1991. Miniaturization of three carbohydrate analyses using a microsample plate reader. Anal. Biochem. 195: 93-96.

Fukuda, M.G.W., Costa, I.R.S, Vilarinhos, A.D. and de Oliveira, R.P. 1996. Banco de germoplasma de mandioca: Manejo, Conservação e Caracterização. Documentos CNPMF No. 68. p103, Cruz das Almas, BA, Brasil.

Hawker, J.S., Ozbun, J.L., Ozaki, H., Greenberg, E. and Preiss, J. 1974. Interaction of spinach leaf adenosine diphosphate glucose $\alpha-1,4$ glucan- $\alpha-4$-glucosyl transferase in synthesis of branched $\alpha$-glucan. Arch. Biochem. Biophys. 160: 530-551.

Hizukuri, S. 1985. Relationship between the distribution of the chain length of amylopectin and the crystalline structure of starch granules. Carbohydr. Res. 141: 295-306.

Hizukuri, S. 1986. Polymodal distribution of chain lengths of amylopectins, and its significance. Carbohydr. Res. 147: 342347.

Lisboa, C. 1631. História Animal e Árvores do Maranhão. Page 176

Macdonald, F.D. and Preiss, J. 1983. Solubilization of the starch-granule-bound starch synthase of normal maize kernel. Plant Physiol. 73: 175-178.

McNeil, M., Darvill, A.G., Aman, P., Franzen, L.E. and Albersheim, P. 1982. Structural analysis of complex carbohydrate using high-performance liquid chromatography, gas chromatography, and mass spectrometry. Meth. Enzymol. 83: 3-45.

Munyikwa, T.R.I. 1997. Isolation and characterization of starch biosynthesis genes from cassava (Manihot esculenta Crantz). Ph.D. Dissertation, Wageningen University, Wageningen, Netherlands.

Munyikwa, T.R.I., Langeveld, S., Jacobsen, E. and Visser, R.G.F. 1997. Cassava starch biosynthesis: new avenues for modifying starch quantity and quality. Euphytica 96: 65-75.

Nakamura, Y., Umemoto, T., Takahata, Y., Komae, K., Amano, E. and Satoh, H. 1996. Changes in structure of starch and enzyme activities affected by sugary mutations in developing rice endosperm. Possible role of starch debranching enzyme (R-enzyme) in amylopectin biosynthesis. Plant Physiol. 97: 491-498.

O'Hair, S.K. 1989. Cassava root starch content and distribution varies with tissue age. HortScience 24: 505-506.

Olsen, K.B.A. and Schaal. 1999. Evidence on the origin of cassava: phylogeography of Manihot esculenta. Proc Natl. Acad. Sci. USA 96: 5586-5591.

Rateaver, B. 1951. Anatomy and regeneration in the stem and root of Manihot utilissima Pohl. Ph.D. Dissertation, University of Michigan, Ann Arbor, MI.

Reiter, W.D., Chapple, C.C.S. and Somerville, C.R. 1993. Altered growth and cell walls in a fucose-deficient mutant of Arabidopsis. Science 261: 1032-1035.

Reiter, W.D., Chapple, C.C.S. and Somerville, C.R. 1999. Mutants of Arabidopsis thaliana with altered cell wall polysaccharide composition. Plant J. 12: 335-345.

Salehuzzaman, S.N.I.M., Jacobsen, E. and Visser, G.F. 1992. Cloning partial sequencing and expression of a cDNA coding for branching enzyme in cassava. Plant Mol. Biol. 20: 809-819. Salehuzzaman, S.N.I.M., Jacobsen, E. and Visser, R.G.F. 1993. Isolation and characterization of cDNA encoding granule- 
bound starch synthase in cassava (Manihot esculenta Crantz) and its antisense expression in potato. Plant Mol. Biol. 20: 947-962.

Sarmento, S.B.S. 1997. Caracterização da fécula de mandioca (Manihot esculenta C.) no período de colheita de cultivares de uso industrial. Ph.D. Dissertation, Universidade de Sao Paulo, Piracicaba, SP, Brazil.

Singletary, G.W., Banisadr, R. and Keeling, P. 1997. Influence of gene dosage on carbohydrate synthesis and enzyme activities in endosperm of starch-deficient mutant of maize. Plant Physiol. 113: 291-304.

Sivad, M.N. and Preiss, J. 1998. Starch: basic science and biotechnology. Adv. Food Nutr. Res. 41: 1-167.

Sriroth, K., Santisopasri, V., Petchalanuwat, C., Kurotjanawong, K., Piyachomkwan, K. and Oates, C.G. 1999. Cassava starch granule structure-function properties: influence of time and conditions at harvest on four cultivars of cassava starch. Carbohydr. Polym. 38: 161-170.
Travaços, S. 1596. Declaração do Brasil XLVII (Brazilian Declaration XLVII), p. 35.

Waigh, T.A., Perry, P., Riekel, C., Gidley, M.J. and Donald, A.M. 1998. Chiral side-chain liquid-crystalline polymeric properties of starch. Macromolecules 22: 7980-7984.

Zakhia, N., Whaetley, C., O'Brien, G.O. and Dufour, D. 1995. Screening of CIAT cassava germplasm diversity: the relationship between cyanogenic potential and cassava starch functional properties. In: The Cassava Biotechnology Network. Proceedings of the 2nd International Scientific Meeting (Bogor, Indonesia, 22-23 August 1994), Centro Internacional de Agricultura Tropical, Cali, Colombia, pp. 823-830.

Zeeman, S.C., Umemoto, T., Lue, W.L., Yeung, P.A., Martin, C., Smith, A.M. and Chen, J. 1998. A mutant of Arabidopsis lacking a chloroplastic isoamylase accumulates both starch and phytoglycogen. Plant Cell 10: 16991711. 